\title{
Structure and Taxonomic Status of Trichogloea Herveyi ${ }^{1}$ )
}

\author{
Wm. Randolph TaYLoR, \\ Professor of Botany, University of Michigan
}

In March 1915, F. S. Collins issued in Fascicle XLI of the Phycotheca Boreali-Americana a specimen (no. 2034) bearing the name Trichogloea Herveyi, ascribing it to W. A. SETCHELL as a manuscript name, doubtless expecting that SETCHELl would soon publish an account of it. The plant still was undescribed when CoLLins and HERVEY (1917, p. 98) published their Algae of Bermuda, and seems still a nomen nudum (PAPENFUss 1946, p. 420). In the course of time a few other Bermudian collections have been made, but the plant is unknown elsewhere (Howe 1918, p. 511). It is not apparent why SETCHELL never legitimized the name.

In 1949 we found the plant not at all rare. It grew at somewhat lesser depths than Dudresnaya, but in not dissimilar-situations, and was likewise a species of the late spring flora. As a large and conspicuous alga it was easy to secure ample material for morphological study, and the writer has come to the conclusion that the species is taxonomically very distinct, so that its name must be confirmed.

This species forms a large gelatinous clump from its little holdfast, generally branching rather sparingly with considerable distances between divisions, but because of the unusual thickness of the branches the plant seems bulky and very crowded. It is more massive and of duller, more purplish color than Dudresnaya. The cortex is composed of rather sparingly branched assimilatory filaments, which increase in diameter until near the ends, with the cells becoming more turgid (Fig. 1). From the slender lower cells of the innermost cortical branches rhizoidal outgrowths about $3.5 \mu$ diam. are developed, which supplement the medullary filaments as the plant increases in size.

1) This work was facilitated by a Grant from funds placed at the disposal of the Bermuda Biological Station by the American Philosophical Society. For this generous aid, and for the very cordial coöperation of the former Director of the Station, Dr. D. E. S. BRown, of the Station staff, and of his assistant under the Grant, Mr. AlBERT J. BeRNatowicz, the writer is exceedingly grateful. Publication no. I60 from the Bermuda Biological Staticn. 


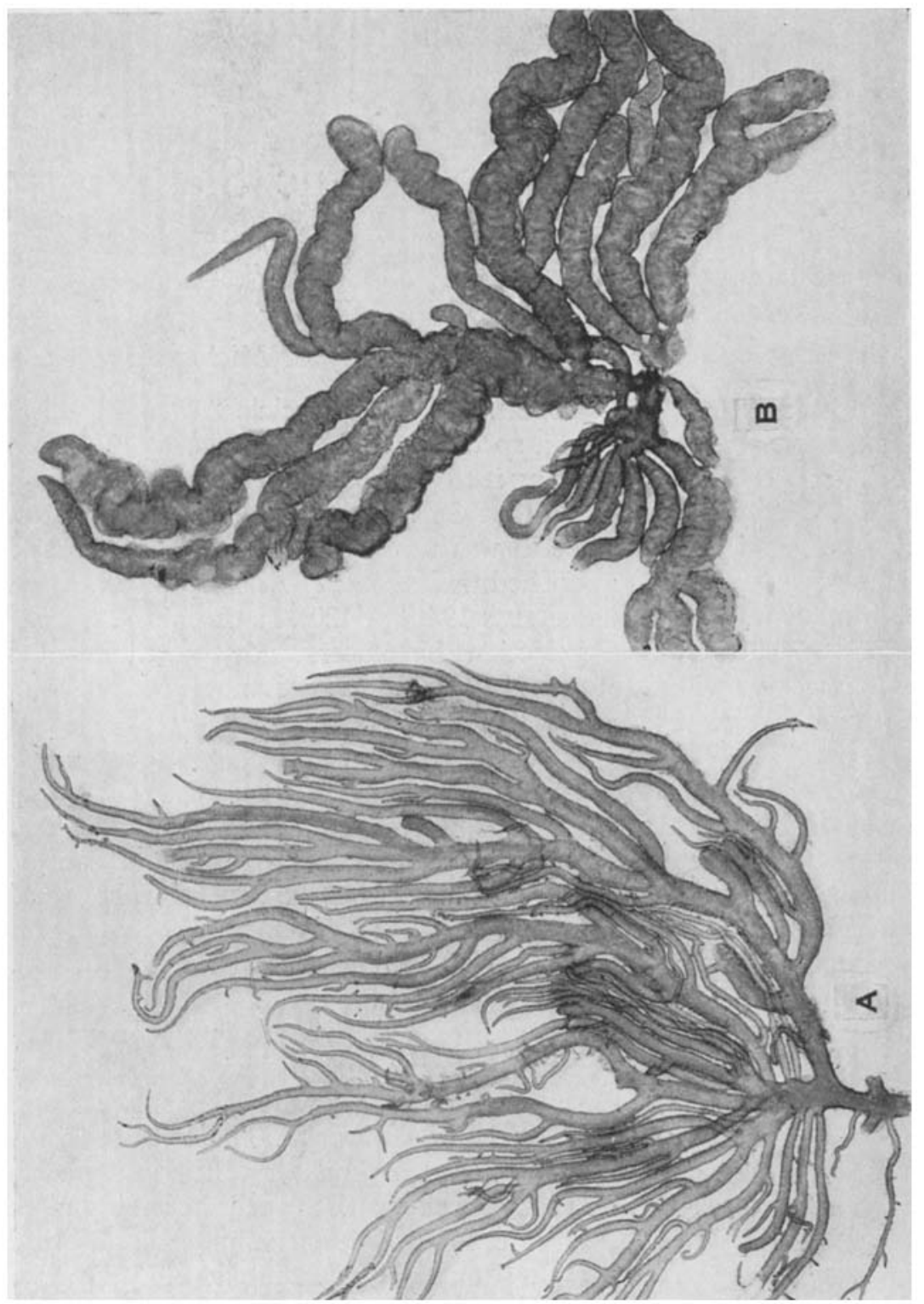

Trichogloea Herveyi - Figure A, a portion of a slender plant, $\times 0.48$. Figure B, a portion of a plant with thick, intestiniform branches, $x \quad 0.57$. There is no correlation between the size of the plant and the coarseness of the branches. 
They arise singly, or oppositely in pairs, diverging nearly at rightangles from the supporting cell well above its lower end, perhaps 2-5 times the diameter. Branching of the cortical filaments near the medulla is also at very wide angles, but nearer the surface quite narrow. The chromatophores are mainly found in the cortex, and are largest in the outer cells, where they show most clearly their lacerate margins (Fig. 2). The medulla of T. Herveyi is relatively illdefined. It can sometimes be recognized in dried specimens by a difference in color or texture of the specimen, but not usually.

Spermatangia occur on the cortical filaments near the outer end; usually, though not always, the outer one or two cells are sterile, and several cells below them fertile. So far as noted, male and female plants have usually been distinct in this species, but the condition is somewhat irregular, for clear instances have been seen where both sexes were found in the same part of a plant, though not on the same cortical filament.

Carpogonia are formed terminally on filaments in the cortex. The portion which may be considered a carpogenic branch is ill-defined, but about five to seven or eight cells in length (Figs. 3, 4). The carpogonium is relatively narrow when mature but unfertilized, with a nearly straight trichogyne the length of which is determined by proximity to the surface of the gelatinous matrix, through which it protrudes (Fig. 7). The cell immediately below the carpogonium usually remains naked (Figs. 4-7), but below this in turn several cells develop small involucral filaments. These are formed near the upper end of each cell, but not strictly in one whorl, and increase in number with age (Figs. 3, 4). They never become very long, branching once or twice successively; the cells are about 2.5-3.5 $\mu$ diam. when young, but when older the cells are considerably larger. After fertilization the carpogonium enlarges and divides transversely by an easily recognizable thin wall (Figs. 5, 6). A lateral protuberance is developed from the distal half, and this is cut off as the first gonimoblast rudiment (Fig. 7). Continued growth and close forking of the gonimoblasts produces a dense cystocarp (Fig. 10). After the first stages (Figs. 8, 9) are passed, the gonimoblast filaments appear relatively slender, with cells $3-4$ times as long as broad, until near maturity. Then certain of the terminal cells enlarge to form the carpospores among the remaining slender filaments. Inner cells of the gonimoblasts may participate in the general but moderate enlargement of the upper cells of the carpogenic branch, which is accompanied by a resorption of the intercellular walls. Growth of the involucre soon causes it to make contact with the lower part of the cystocarp, and it becomes very dense, completely obscuring the 
axis, the cells of which, however, are neither greatly enlarged nor their intercellular connections much distended (Figs. 9, 10).

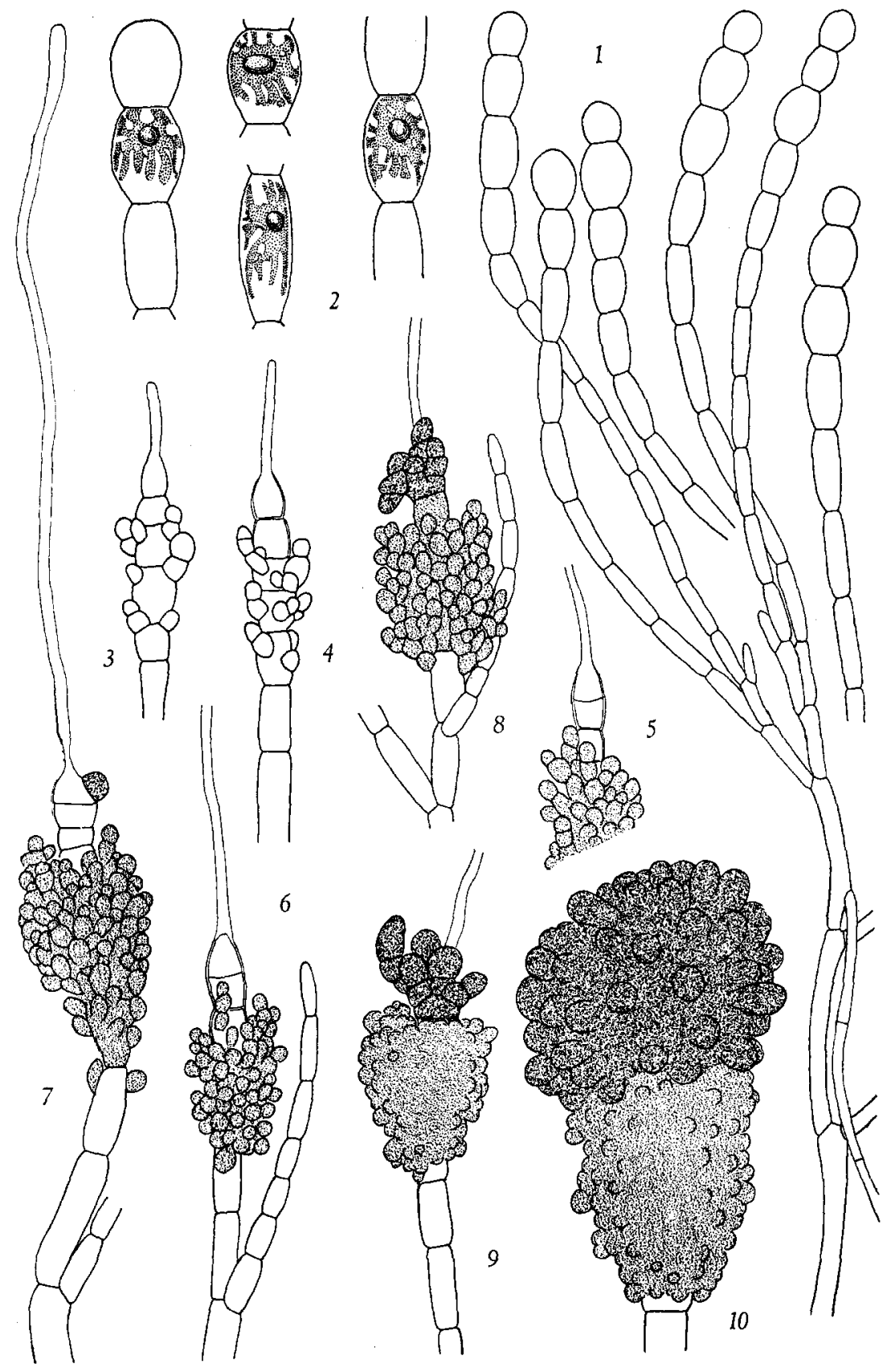


At the time Collins issued his Bermuda specimen as Trichogloea Herveyi no detailed comparison had been made of the hitherto known species, but Howe (1934, p. 33) in developing the distinctions for an Hawaiian plant has noted the characters of two others as well, giving photographs of authentic material of the classical T. Requienii (Mont.) Kütz. from the Red Sea (1934, p. 36, textfig. 3) and T. lubrica (Harv.) J. Agardh from Ooleva in the Friendly (Tonga) Islands (1934, p. 35, textfig. 2). Trichogloea Herveyi lacks the white calcified axis which these other forms show. While T. lubrica is of similar habit to some extent, and similarly has a small-celled compact involucre, the diameters of the cells of the outer cortical filaments is a little less (to $15-16 \mu$ ), the cells probably more generally cask shaped, and the carpospores are considerably smaller than in $T$. Herveyi. The species with which HowE's paper was primarily concerned, $T$. sub$n u d a$, has almost no involucre at all.

Before we can close these comparisons we must consider the case of the Guadeloupe Helminthocladia Cassei, essentially a nomen nudum, absent from the first two editions of Mazé and SCHRAMm's Essai......, appearing on p. 177 of the $1870-1877$ edition, and on the specimens which they distributed. For this study, as for others, Dr. D. P. ROGERS of the New York Botanical Garden kindly loaned the Collins and the Howe specimens, while Dr. W. L. WHIrE of the Farlow Herbarium, Cambridge, loaned the materials in that collection, notably those of FARLOW. Included in these collections were several annotated by SETCHELL. In particular, M. ROBERT LAMI of the Museum National d'Histoire Naturelle, Paris, sent photographs of both sterile and cystocarpic plants of no. 35 of the MAZÉ and SCHRAMM Guadeloupe algae, from the Crouan collection in the Thuret Herbarium, and adequate fragments for the determination of the microscopic characters. A photograph of MAZÉ's specimen no. 243, which

Figures I-IO. Trichogloea Herveyi. Magnifications all $\times 500$, except fig. I. Fig. I, cortical filaments from near their connection with the primary medulla, including one rhizoidal outgrowth supplementary to the medulla, but which would ordinarily diverge from its supporting cell at right angles, $\times 285$. Fig. 2, portions of four cortical filaments, to show the chromatophores and pyrenoids. Figs. 3, 4, immature carpogenic branches, the trichogynes only partly extended, but the formation of involucral filaments well started. Figs. 5, 6, carpogenic branches after fertilization, showing the first, transverse, division of the carpogonium, and the increased involucre. Fig. 7 , initiation of the gonimoblast by cutting off of a lateral protuberance from the distal half of the carpogonium. Figs. 8, 9, further stages in the early development of the gonimoblasts, during which the involucre becomes exceedingly dense. Fig. 10, mature cystocarp with densely packed mass of involucral filaments below it. 
reached a height of about $17 \mathrm{~cm}$., in the herbarium of the British Museum (N.H.), and a slide in the herbarium of the New York Botanical Garden, leave no doubt that the plant is a Trichogloea, but as the material is spermatangial further progress cannot be made through it. Specimen no. 35, the first mentioned in the Essai...., in the cystocarpic individual supplies the deficiency admirably, and constrains the writer to the opinion that there are no essential differences between the Guadeloupe material reported as $H$. Cassei, and $T$. Requienii, either in vegetative filaments, number and arrangement of the involucral filaments, or in the carpospores. For this very generous help the writer is much indebted to M. Lami.

There are in the herbarium of the New York Botanical Garden several Puerto Rican specimens which show all of the characters of the Guadeloupe $H$. Cassei, but are richly fruited. For comparison a description is offered, based primarily on the histological characters of the Guadeloupe specimens in the Thuret herbarium, but including Howe's Puerto Rico material. Trichogloea Requienii (Mont.) Kütz. Plants reaching $20 \mathrm{~cm}$. in height, repeatedly branched from a small holdfast, bushy, purplish red. Main branches $2-4 \mathrm{~mm}$. diam., the lesser branches $1.0-2.0 \mathrm{~mm}$. diam. Cortex $0.5-1.0 \mathrm{~mm}$. thick, gelatinous, the cortical filaments with outer cells cask-shaped to truncate ovoid, $12-22 \mu$ diam., 22-28 $\mu$ long, but more slender toward the medulla. Medulla $1-2 \mathrm{~mm}$. diam., markedly calcified, perceptibly thicker, raised, white and sharply delimited in dried specimens. Monoecious, the spermatangia whorled on $1-5$ cells of the cortical filaments, terminal or more usually $2-5$ cells distant from the outer ends. Carpogonia terminating cortical filaments, the lower 3-4 cells of the carpogenic branch sparingly developing once or twice-branched involucral filaments, the end cells 3.5-5.5 $\mu$ diam. on young axes (but on Puerto Rican specimens to 8-10 $\mu$ diam. on old ones), not forming a dense mass below the cystocarp, the whorls sparse and remaining well separate. Axis bearing the involucre about $8 \mu$ diam. when young, becoming $15-25 \mu$ diam. below the older cystocarps with complete resorption of at least the upper $2-3$ cross-walls. Cystocarps to $45-95 \mu$ diam. (and to $145 \mu$ in Puerto Rican specimens), the very numerous carpospores to $5.5-$ $9.3 \mu$ diam., $10-12 \mu$ long.

It is true that we must draw most of our data on $T$. Requienii from other than Red Sea material, but the figure given by NASR (1947, p. 95, fig. 17), while uncertain as to cross-walls in the lower carpogenic axis, shows it enlarged and with a loose involucre. BøRGESEN's Mauritius specimen, on the other hand $(1942$, p. 18, fig. 7) shows the axis 
tapering into the cystocarp and with complete cross-walls; Mauritius material in the Garden herbarium collected by Nicholas Pike ( no. 194) in 1869 (incorrectly labeled Myriocladia capensis) does not have the habit of the Red Sea plant, is nearly lime-free, is spermatangial, but may well be a different species from what Børgesen had in hand. PAPENFuss (1946, p. 419) presents a convincing case for the presence of $T$. Requienii in Hawaii and other Pacific areas, and has given us the best study we have of reproductive structures in the species.

We have, then, in the West Indies a second Trichogloea in addition to T. Herveyi, with calcified medulla, a rather sparse or at least loosely disposed and rather large celled involucre, and relatively small carpospores, which we may best call Trichogloea Requienii (Mont.) Kütz. The piece of T. lubrica in HAMEL and HAMEL-Joukov, Algues des Antilles Françaises no. 35 from Guadeloupe in the Herbarium of the University of Michigan is too fragmentary to give an idea of the habit of the plant, but it has the calcified medulla and loose, coarse involucre of T. Requienii. The specimen labeled T. lubrica in VICKERS, Algues de la Barbade no. 100 in the Herbarium of the New York Botanical Garden has a rather lightly calcified medulla and more substantially developed involucral filaments than some of the specimens of $T$. Requienii, but they are no more prominent than some from Waikiki Beach, Oahu, in the writer's herbarium which resemble closely the plant figured by PaPenfuss (1946, fig. 1). The plant could not be T. Herveyi, as here defined. Disposition of Nemalion barbadense VICKERS (1905, p. 60), which has been referred to Trichogloea, had best be left in abeyance until fruiting material from the type locality is available, since she mentions that sexual plants were not found by her, and that her plant had monospores.

In summary, then, we have in Bermuda a Trichogloea, slender to coarse, essentially uncalcified, with a dense, small-celled involucre which we may continue to call $T$. Herveyi, and in the West Indies a more slender species, $T$. Requienii, with calcified axis and loose, coarse involucre. The first is, so far as our records go, endemic; the second has a scattered distribution throughout the tropics.

Trichogloea Herveyi n. sp. ${ }^{1}$ - Plants bushy, to $17 \mathrm{~cm}$. tall, highly

1) Trichogloea Herveyi n. sp. - Plantae altitudinum $17 \mathrm{~cm}$. attingentes, e haptero parvo fruticosae, sordide sub-purpureo-rubrae, ut videtur, non calcifactae; identidem alterne ramosae, ramis principalibus $4-8 \mathrm{~mm}$. diam., ramis secondaris $1.5-2.0 \mathrm{~mm}$. diam. Filamenta corticea $18-20 \mu$ diam., cellulis truncatis, obovoideis ovatisque in parte exteriore, tenuia, autem, prope medul- 
gelatinous and very soft, dull purplish red, uncalcified, or a little invisible entirely diffuse calcification present; subsessile from a small holdfast, repeatedly alternately branched, the branches to $8 \mathrm{~mm}$. diam., more generally about $4 \mathrm{~mm}$. diam. below, $1.5-2.0 \mathrm{~mm}$. in the lesser branches, which taper to more or less blunt apices, and are generally not crowded, but occasionally the branching is dense, short and coralloid. Cortical assimilatory filaments slender near the medulla, reaching $18-20 \mu$ diam. in the distal portion, the outer cells oval to obovoid, truncate, each with a single lacerate chromatophore and a prominent pyrenoid. Medulla not perceptibly calcified, rarely slightly thicker in dried specimens. Medullary filaments di-trichotomously or irregularly branching at wide angles, in young branches 5.5$8.5 \mu$ diam. Spermatangia delicate, $2.5-3.5 \mu$ diam., usually two on each little stalk cell, whorled near the outer ends of $3-5$ terminal or subterminal cells of the cortical filaments. Carpogonia terminal on divisions equivalent to ultimate cortical filaments, about 3-5 of the lower cells of the carpogenic branch portion developing short 1-3times divided involucral filaments, the outer cells of which below old cystocarps reach 4.5-5.5. $\mu$ diam. Cystocarps immersed in the outer portion of the cortex, small, 50-120 $\mu$ diam., the obovoid carpospores formed from terminal cells of the gonimoblasts, $10.0-$ $12.5 \mu$ diam., $15.0-17.0 \mu$ long.

Distribution: Bermuda, St. Georges I., south shore of Whalebone Bay, on stones exposed at extreme low tide, A. J. Bernatowicz no. 49-314, 16 March 1949 Ibid., no. 49-972, 27 April 1949. Ibid., Achilles Bay, adrift, no. 49-580, 1 April 1949. Ibid., on stones $3 \mathrm{dm}$. below low tide, no. 49-2031, 11 June 1949. Ibid., Buildings Bay, adrift, no. 49-1569, 4 March 1949. Smiths I, north side near Pitchers Point, no. 49-1608, 7 May 1949. St. Davids I , entrance to Gunners Bay, no. 49-658, 9 April 1949. Ibid., rare on a barely immersed rock, no. 49-1976, 9 June 1949. Nonsuch I., rare, on rocks in the surf zone of Cock Rocks, W. R. Taylor and A. J. Bernatowicz no. 49-542, 28 March 1949. Castle I., occasional on rocks of south side to a depth of $6 \mathrm{dm}$., no. $49-514$ (coarse form) and $49-515$ (slender form), 28

\footnotetext{
lam. Plantae monoeciae aut, ut videtur, dioeciae, spermatangiis in filamentis corticeis verticellos efficientibus. Carpogonia filamenta cortica terminantia, cellulis inferioribus rami carpogenici filamenta involucralia creberrima infra custocarpum efficientibus, cystocarpo usque ad 50-I20 u diam. crescente. Hoc nomine a notabili phycologista W. A. SETCHELlo primum proposito, quamquam haec species ab eo descripta esse non videtur, velut typum technicum asciscere nobis licet specimen no. 2034 Phycotheca Boreali-Americanae in Herbario F. S. CollinsI in "New York Botanical Garden". Hoc specimen a F. S. Collinsio collectum erat ad "Coopers Island" in Colonia Bermudae, 29. $\mathrm{m}$. Apr. I912, et veri simile est materiam huius collectionis Prof. SETCHELlo ad manum fuisse.
} 
Mar. 1949. Charles I., on rocks $3 \mathrm{dm}$. below low tide, A. J. Bernatowicz no. 49-1825, 25 May 1949. Hamilton I., scarce in tidepools at the head of Gravelly Bay, very coarse, no. 49-738, 11 April 1949. Ibid., between Wreck Bay and the entrance to Elys Harbor, W. R. Taylor and A. J. Bernatowicz, no. 49-1672, 9 May 1949.

\section{REFERENCES}

Børgesen, F. 1942. - Some Marine Algae from Mauritius, III. I. Porphyridiales, Bangiales, Nemalionales. K. Danske Vidensk. Selsk., Biol. Medd. 17 (5) : $I-64,27$ textfigs., 2 pls.

Collins, F. S. and A. B. Hervey. 1917. - The Algae of Bermuda. Proc. Amer. Acad. Arts and Sci. 53: I-192, 6 pls.

Howe, M. A. - Algae, pp. 489-540, In: N. L. Britton, Flora of Bermuda xi + 585 pp., illus. New York, I9I8.

__ I I934. - Hawaiian Algae Collected by Dr. Paul C. Galtsoff. Fourn. Washington Acad. Sci. 24 (I): 32-42, 5 textfigs.

NaSR, A. H. I947. - Synopsis of the Marine Algae of the Egyptian Red Sea Coast. Bull. Fac. Sci., Fouad I. Univ., no. 26: I-155, 24 textfigs., I4 pls.

PAPENFUSS, G. F. 1946. - Structure and Reproduction of Trichogloea Requienii, with a Comparison of the Genera of Helminthocladiaceae. Bull. Torrey Bot. Club 73 (5): 419-437, 26 textfigs.

VICKers, A. 1905. - Liste des Algues Marines de la Barbade. Ann. Sci. Nat., Bot. ix, I: 45-66. 